\title{
Hepatoprotective Effect of Chenopodium Album Linn. Whole Plant on Biochemical Parameters Against Paracetamol Induced Hepatotoxicity in Rats
}

\author{
Maliha Ata ${ }^{1 *}$ \\ Selim Md Jahangir ${ }^{2}$ \\ Md Mahbubul Islam ${ }^{2}$ \\ Rasheda Akter $^{3}$ \\ Md Tofayel Hossain Sarkar ${ }^{3}$ \\ Gias Uddin ${ }^{4}$ \\ Zahangir Alam Chowdhury ${ }^{5}$ \\ Rajat Sanker Roy Biswas ${ }^{6}$
}

${ }^{1}$ Department of Pharmacology \& Therapeutics Southern Medical College, Chittagong, Bangladesh.

${ }^{2}$ Department of Pharmacology \& Therapeutics Chittagong Medical College, Chittagong, Bangladesh.

${ }^{3}$ Bangladesh Council of Scientific \& Industrial Research, Chittagong, Bangladesh.

${ }^{4}$ Department of Psychiatry

Chattagram Maa-O-Shishu Hospital Medical College Chittagong, Bangladesh.

${ }^{5}$ Department of Physical Medicine \& Rehabilitation Chattagram Maa-O-Shishu Hospital Medical College Chittagong, Bangladesh.

${ }^{6}$ Department of Medicine

Chattagram Maa-O-Shishu Hospital Medical College Chittagong, Bangladesh.

${ }^{*}$ Correspondence to:

\section{Dr. Maliha Ato}

Assistant Professor

Department of Pharmacology \& Therapeutics

Southern Medical College

Chittagong, Bangladesh.

Mobile : +8801910837966

E-mail:maliha59@gmail.com

www.banglajol.info/index.php/CMOSHMC

\begin{abstract}
Chenopodium album Linn (Called Bathua in Bengali) is a plant which has a long history of uses in liver disorders in this subcontinent. This study was done to evaluate the hepatoprotective effects of ethanol extract of this plant on paracetamol induced hepatotoxicity in albino rats. The total experiments were designed as follows (I) Experiment (part I):- Induction of hepatotoxicity by single administration of paracetamol at a dose of $2 \mathrm{gm} / \mathrm{kg}$ body weight. (2) Experiment (part II) : Effects of ethanol extract of Chenopodium album Linn. on paracetamol induced hepatotoxicity in albino rats. The biochemical reports suggested that acute administration of paracetamol produced significant hepatotoxicity in experimental rats which was evidenced by significant increase in Serum Bilirubin, Serum Alanine Aminotransferase (ALT) Serum Aspartate Aminotransferase (AST) Serum Alkaline Phosphatese (ALP) level, decrease in serum albumin and serum total protein level. When rats were treated with extracts of $C$. album plant in paracetamol induced hepatotoxic albino rats, the results showed marked reduction in serum bilirubin, serum ALT, serum AST and serum ALP level and increase of serum albumin level but not sigificant increase of total protein as compared with paracetamol treated group. The results of the present study revealed that ethanol extract of Chenopodium album Linn. whole plant has got protective effects against paracetamol induced hepatotoxicity. Further study is needed to find out the curative effect and to isolate the active principle and to explore out the exact hepatoprotective mechanism of this plant extract.
\end{abstract}

Key words: Chenopodium album Linn; Hepatoprotective; Hepatotoxicity; Paracetamol.

\section{INTRODUCTION}

The use of plants as medicines predates written human history. A large amount of archaeological evidence exists which indicates that study of herbs dates back over 5,000 years to the Sumerians, who created clay tablets with lists of hundreds of medicinal plants. In 1500 B.C, the ancient Egyptians wrote on the Papyrus, which contains information on over 850 plant medicines, including garlic, juniper, cannabis, castor bean, aloe etc. About 200 years ago, the first pharmacologically active pure compound, morphine, was produced from opium extracted from seeds of the poppy (Papaver somniferum). This discovery showed that drugs from plants can be purified and administered in precise dosages regardless of the source of the material ${ }^{1-2}$. Between 2005 and 2007, 13 drugs derived from natural products were approved in the United States and of the total 252 drugs in the World Health Organization's (WHO) essential medicine list, $11 \%$ are exclusively of plant origin ${ }^{3}$. 
Uses of herbal drugs in the treatment of liver diseases has a long tradition, especially in Eastern medicine and can be traced back as far as 2100 B.C, in ancient China (Xia Dynasty) and India (Vedic period), but evidence for efficacy is sparse ${ }^{4}$. Now, it is necessary to search for drugs of plant origin scientifically for the treatment of liver disease in order to replace currently used drugs of doubtful efficacy and safety. Bathua Shak, scientific name is Chenopodium album Linn. belongs to family Chenopodiaceae may be source of drug for the protection of hepatotoxicity. This plant is available in our country and widely used by the traditional healers in the treatment of jaundice but scientific basis of such use is not specifically known. So in the present study, an attempt has been made to validate the traditional use of this plant as hepatoprotective against experimentally produced hepatotoxicity.

\section{MATERIALS \& METHODS}

\section{Animals:}

Total 30 Albino rats (Rattus norvegicus) of age 3 to 6 months and body weight of 140-250 gm were used in this study, which were collected from Bangladesh Council of Scientific \& Industrial Research (BCSIR).

\section{Drugs, plants and chemicals:}

i) Paracetamol (Acetaminophen) Powder (100 gm): Obtained from Glaxo Pharmaceuticals Bangladesh Limited.

ii) Chenopodium album Linn. plant: Identified in the Industrial Botany division of Bangladesh Council of Scientific \& Industrial Research (BCSIR) laboratory, Chittagong. Ethanol extract prepared in the laboratory of BCSIR.

iii) 95\% Ethanol: Purchased from Chittagong scientific store, Chittagong.

iv) Propylene Glycol: Purchased from Chittagong scientific store, Chittagong.

\section{Preparation of solution:}

Solution of Paracetamol: $500 \mathrm{mg}$ of Paracetamol powder (Active ingredient) was dissolved in $2 \mathrm{ml}$ propylene glycol, so as to obtain a concentration of $250 \mathrm{mg} / \mathrm{ml}$.

Preparation of plant extract: $500 \mathrm{mg}$ of plant extract was diluted in $5 \mathrm{ml}$ of distilled water, so as to obtain a concentration of $100 \mathrm{mg} / \mathrm{ml}$.

\section{Preparation of Ethanol extract of C. Album plant:}

The plant of Chenopodium album Linn. (Bathua shak) was identified in the Industrial Botany Division of BCSIR laboratory, Chittagong. Freshly collected whole plant of C. album was washed separately, cut into small pieces, air dried at room temperature for about 10 days and ground into powder form. Then the powder was macerated in 95\% ethanol for 5-7 days at room temperature with occasional stirring. The ethanol extract of plant collected in a container and concentrated under reduced pressure below $50^{\circ} \mathrm{C}$ through rotatory vacuum evaporator.
The concentrated extract was collected in a petridish and allowed to air dry for complete evaporation of ethanol. The concentrated extract then dried using freeze dryer. Finally an approximately $50 \mathrm{gm}(10 \% \mathrm{w} / \mathrm{w})$ dark green sticky mass was obtained and was kept in a refrigerator at $4^{\circ} \mathrm{C}$. During study $100 \mathrm{mg} / \mathrm{ml}$ concentrated extract was prepared by using distilled water.

\section{Study design:}

For convenient purpose of study, the experiment was divided into 3 parts: Part - I, Part - II and Part - III.

\section{Experiments:}

Part I: Induction of hepatotoxicity by Paracetamol

18 rats were randomly selected for this part of experiment and divided into following three groups as Group-A1, Group-B1 and Group C1. Each group contained 6 rats.

Group A1 (Control): The rats in this group served as control and received distilled water $2 \mathrm{ml}$ per oral through stomach tube for 7 days.

Group B1 (Vehicle control): The rats of this group served as vehicle control and received single dose of propylene glycol (vehicle for Paracetamol) $2 \mathrm{ml}$ orally by stomach tube.

Group C1 (Paracetamol treated): This group received single dose of Paracetamol solution in propylene glycol at a dose of $2 \mathrm{gm} / \mathrm{kg}$ body weight in the strength of $250 \mathrm{mg} / \mathrm{ml}$ of solution. Animals were sacrificed 48 hours after the administration of Paracetamol $^{5}$. Blood was collected by cardiac puncture ${ }^{6}$.

Part II : Effects of pre treatment with Chenopodium album plant extract on Paracetamol induced hepatotoxicity in rats.

12 rats were randomly selected for this part of experiment and divided into following two groups as Group-A2, Group-B2. Each group contained 6 rats.

Group A2 (Chenopodium album plant extract): Rats of this group received Chenopodium album plant extract $(500 \mathrm{mg} / \mathrm{kg})$ by stomach tube for 7 days.

Group B2 (Chenopodium album plant extract + Paracetamol): Rats of this group received Chenopodium album plant extract $(500 \mathrm{mg} / \mathrm{kg})$ for 7 days and on the 7 th day toxic dose of Paracetamol $(2 \mathrm{gm} / \mathrm{kg})$ administered per oral through stomach tube. All the rats were sacrificed on the 9th day that is, 48 hours after Paracetamol administration ${ }^{5}$. Blood sample was collected from each rat in separate test tube and investigated for biochemical parameters.

\section{Collection of blood and separation of serum:}

Blood was collected by cardiac puncture from each rat in separate test tubes. Test tubes were placed in inclined position, in the dark about 1 hour, at room temperature. The clot was loosened from the wall of the test tubes with a fine clean stick taking care to avoid haemolysis. Serum was then drained off carefully into the centrifuge tube and centrifuged at $3000 \mathrm{rpm}$ for 3-5 minutes. The serum was then collected in the tips and was used for biochemical parameters. 


\section{Parameter studied: Biochemical parameters}

a) Estimation of serum bilirubin - DCA method.

b) Estimation of serum alanine amino transferase (ALT) Kinetic method

c) Estimation of serum aspartate aminotransferase (AST) Kinetic method.

d) Estimation of serum alkaline phosphatase (ALP) Kinetic method.

e) Estimation of serum albumin - Photometric colorimetric test for Albumin (BCG - Method)

f) Estimation of serum total protein -- Photometric Colorimetric test for total proteins (Biuret Method).

\section{Statistical analysis}

All the results have been expressed as mean \pm standard error of mean (Mean \pm SEM). Significance of difference between groups were assessed by using Student's ' $t$ ' test with $\mathrm{P}<0.05$ was considered significant $(*)$ and $\mathrm{p}<0.01 / 0.001$ was considered highly significant $(* * *) . \quad \mathrm{P}>=0.05$ was considered Not Significant (NS)

\section{RESULTS}

In this study, all the biochemical markers (Serum ALT, AST, Alkaline phosphatase \& Bilirubin) increased to highly significant level after Paracetamol administration as compared to the control group and the vehicle control group. These findings indicate that there are extensive liver damage after toxic dose of paracetamol administration. Serum albumin decreased highly significantly as compared to the control and the vehicle control group and total protein decreased highly significantly as compared to the control group and significantly decreased as compared to the vehicle control group after Paracetamol administration. It was observed that when only ethanol extracts of C. album was given to one groups of rats, there was no significant changes in biochemical parameters as compared to the control group. These findings suggest that $\mathrm{C}$. album do not alter normal hepatic function. Pretreatment with C. album in Paracetamol induced hepatotoxic rats showed reduction of serum bilirubin, ALT, AST and ALP level which were statistically highly significant as compared to the Paracetamol

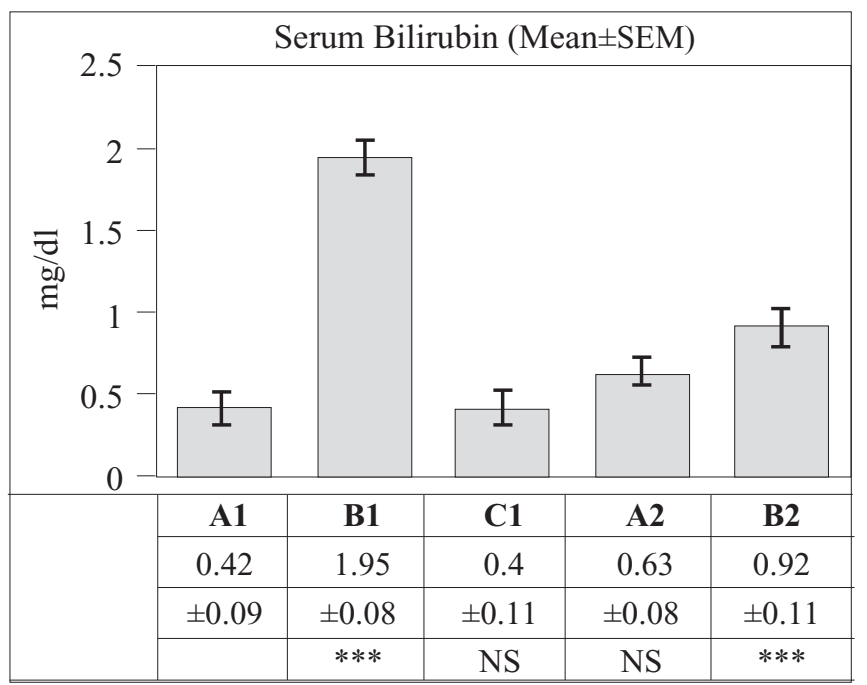

Figure 1 : Bar diagram showing the effect of all group of rats on Serum Bilirubin level. treated group. There was highly significant increase of serum albumin level as compared to the Paracetamol treated group but no significant change was observed in case of serum total protein.

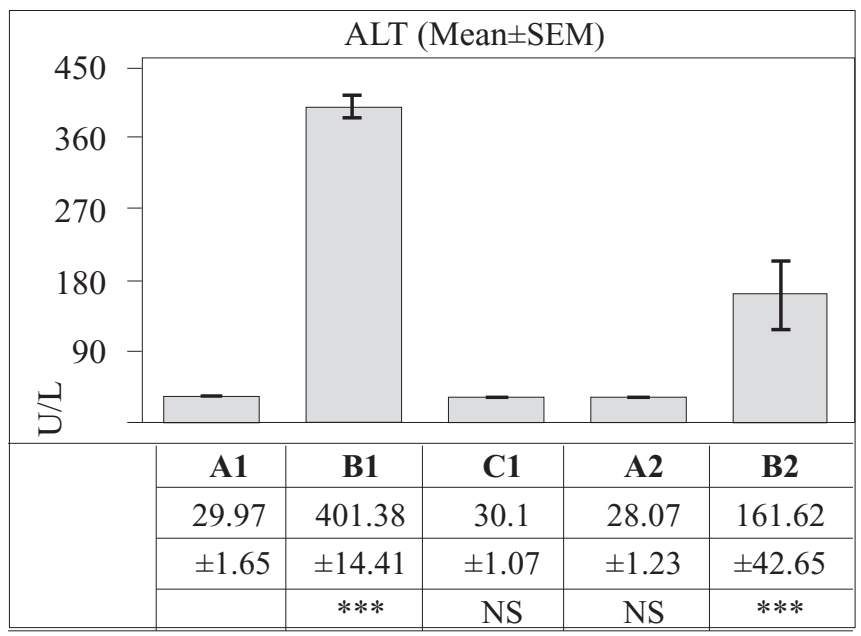

Figure 2 : Bar diagram showing the effect of all group of rats on ALT level.

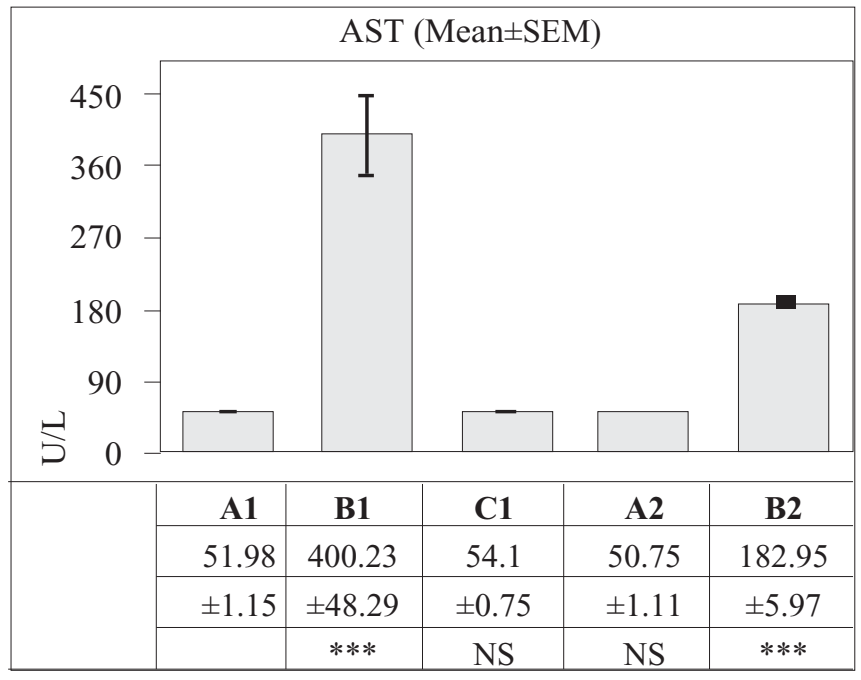

Figure 3 : Bar diagram showing the effect of all group of rats on AST level.

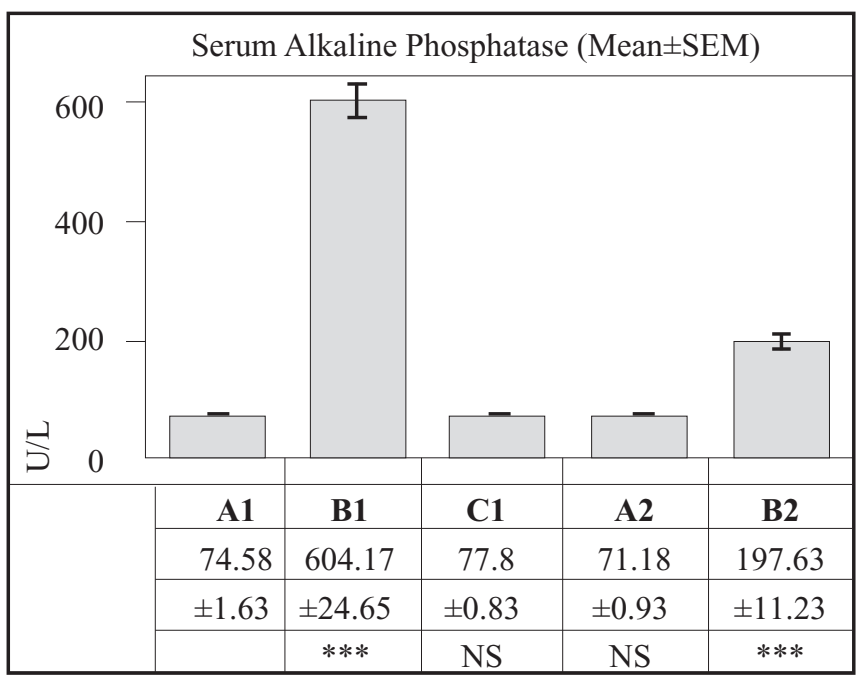

Figure 4 : Bar diagram showing the effect of all group of rats on Serum ALP level. 


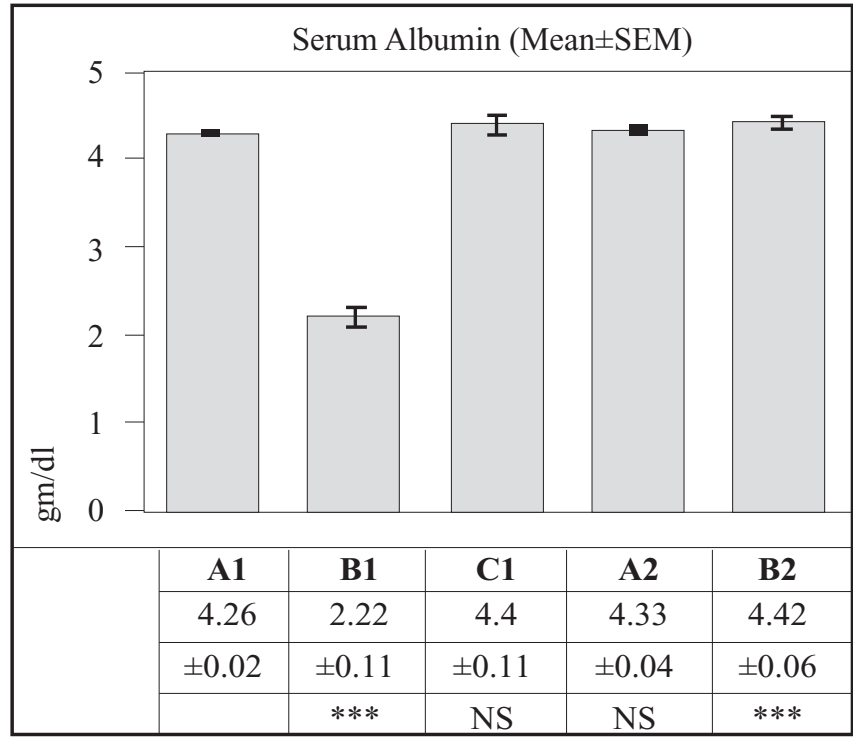

Figure 5 : Bar diagram showing the effect of all group of rats on Serum Albumin level.

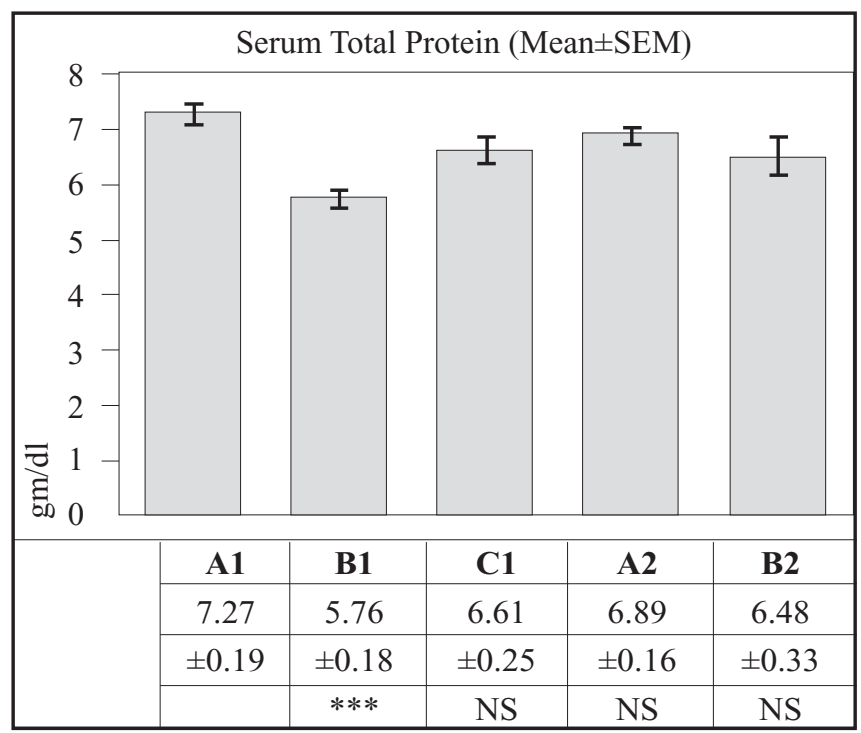

Figure 6 : Bar diagram showing the effect of all group of rats on Serum Total Protein level.

\section{DISCUSSION}

Paracetamol toxicity results from formation of an intermediate reactive metabolite (NAPQI) which binds covalently to cellular proteins, causing cell death. In therapeutic doses, this toxic intermediatemetabolite is detoxified in reactions requiring glutathione, but in overdose, glutathione reserves become exhausted and results in the generation of free radicals following the depletion of glutathione. Antidotes for Paracetamol act by replenishing hepatic glutathione ${ }^{7}$. As pretreatment with $\mathrm{C}$. album produces lesser biochemical changes, it is easily understood that these extracts deserve credit for giving protection to liver. The proposed reasons behind the protection are possibly the GSH preservation or replenishment and antioxidant properties of those extracts ${ }^{8-9}$.

\section{CONCLUSION}

The results of present study clearly demonstrate that various biochemical (Serum AST, ALT, ALP, Albumin, Total Protein and Bilirubin) alterations produced by Paracetamol in the serum were reserved significantly by the pretreatment of whole plant extract of Chenopodium album. So, this study reveals that ethanol extract of Chenopodium album have protective effect against drug induced hepatotoxicity.

\section{DISCLOSURE}

All the authors declared no competing interest.

\section{REFERENCES}

1. Judith S. The Natural History of Medicinal Plants. Timber Press. 2000;17.

2. Hartmann T. Fromwaste products to ecochemicals: Fifty years research of plant secondary metabolism. Phytochemical. 2007;68:2831-2846.

3. Sahoo N, Manchikanti P. Herbal drugs: Standards and regulation.Fitoterapia.2010;81( 6):462-471.

4. Dhiman A, Nanda A, Ahmad, S. A recent update in research on the antihepatotoxic potential of medicinal plants. Journal of Chinese integrative medicine. 2012;10( 2):117-127.

5. Garg NK. Screening of natural product for hepatoprotective activity, Luncknow: division of biochemistry, central research institute. 1995; 189-191

6. Portmann B, Talbot IC, Day DW, Davidson AR, Murray-Lyon IM, Williams R. Histopathological changes in the liver following a Paracetamol overdose: correlation with clinical and biochemical parameters. Journal of pathology. 1975;117:169-181.

7. Colledge NR, Walker BR, Ralston SH. Davidson's principles \& practice of medicine. Churchill Livingstone Elsevier, London. 2010;(21):209-210.

8. Fakurazi S, Hairuszahb I, Nanthinia U. Moringa oleifera Lam prevents Acetaminophen induced liver injury through restoration of glutathione level. Food and chemical toxicology. 2008;46(8): 2611-2615.

9. Jain NK, Singhai AK. Hepatoprotective activity of Chenopodium album Linn: in vitro and in vivo studies. Journal of experimental and integrative medicine. 2012;2( 4):331-336. 